\title{
Salt and Water Deficit Tolerance in some Vicia faba L. Genotypes in Relation to Pigments, ISSR - PCR Markers and Stress Tolerance Indices
}

\author{
S.A. ${ }^{1}$, Afiah, Zinab, A. Abd El- Gawad', Thoria. R. \\ Mohamed $^{2}$, Hasnaa. H. Al-Agwany ${ }^{2}$ \\ ${ }^{1}$ Plant Genetic Resources Department, Desert Research Center, \\ El-Matareya and ${ }^{2}$ Botany Department, Faculty of Women for Arts, \\ Science and Education, Ain Shams Univ., Cairo, Egypt.
}

7 WO POT experiments were conducted to investigate the response of five divergent faba bean genotypes namely (NBL- Mar.3, NBL-5, L3, Nubariya-1 and Misr-1) against either drought or salt stresses with split plot design. To achieve this purpose; some morphological characteristics, pigments, carbohydrates, molecular markers, stress tolerance indices and polymorphic information content (PIC) were recorded.

Expose the faba bean genotypes to water and salt stress leads to significant decrease in photosynthetic pigments, total carbohydrates and starch. A significant increase in total soluble sugar content with increasing the salt and water stress levels were detected in all genotypes. Tolerant genotypes (NBL- Mar.3 and NBL-5) have high chlorophyll, carbohydrates and starch content than sensitive genotypes (Nubariya-1 and Misr-1). Seed yield /plant presence wide range of differences among all genotypes in each of the two abiotic stresses in focus. This reflects a fluctuation response in each of the eleven tolerance indices. NBL-5 considered as the highest drought tolerant genotype while Misr-1 is the most sensitive one. Similar conclusion is true for NBL- Mar.3 as a best tolerant genotype under salinity experiment conditions while, Nubariya-1 and Misr-1 were the most sensitive one. The highest water deficit newly bred tolerant genotype (NBL-5) discriminated by either two positive specific markers at amplified fragments (AF) (45 and 61) or three negative amplicons at $\mathrm{AF}$ (30, 32 and 33). The salt tolerant genotype (NBLMar.3) own ten of the unique amplicons out of the 40 total number of specific markers (TSM) which including either the presence or absence of a given band. These specific markers could be successfully used as marker assisted selection (MAS) for the best genotypes utilizing in faba bean breeding programs. 
The dendrogram results classified the five faba bean genotypes under consideration into two main clusters. The first cluster comprised the two newly bred lines (NBL- Mar.3 and NBL-5) which shared in one parent of their ancestors and this could confirm the highest similarity value between them.

Keywords: Stress tolerance indices, ISSR-PCR markers, Polymorphic Information Content (PIC), Dendrogram.

Faba bean, broad bean or field bean (Vicia faba L.; $2 \mathrm{n}=12$ ) is a major food and feed grain legume owing to the high nutritional value of its seeds, which are rich in protein 27-34\% (Duc, 1997). It is considered as one of the major sources of cheap protein and energy in Africa, parts of Asia and Latin America, where most people cannot afford meat sources of protein (Alghamdi, 2009). In Egypt, faba bean is among the main nutritional source of plant proteins (Bakry et al., 2011). It ranks as the fourth most important legume crop in the world after dry beans, dry peas and chickpea (Toker, 2004). A rich and diverse germplasm collection is the backbone of successful crop improvement for increased crop production. Genetic resources have played a major role in providing source of resistance to biotic and abiotic stresses. It is important not only to collect genetic resources, but also to evaluate, document and utilize these materials for their immediate and long-term use in breeding programs. Nevertheless, the total production of this crop is still limited and falls to cover the increasing local consumption, so there is a prerequisite to enlarge the production by expansion throughout reclaimed areas which signify the scope of cultivated lands (Khalafallah et al., 2008 and Bakry et al., 2011). Nowadays, with increasing the number of faba bean varieties, it is difficult to differentiate these varieties on the basses of morphological characters alone because these characters are either influenced by environmental factors and stage of plant development or reveal limited variation (Terzopoulosa and Bebeli, 2008).

Recently, DNA-marker approaches have become gradually more utilized for taxonomic and phylogenetic analyses. They are not affected by environmental factors or by plant developmental stages. Besides, these approaches have potential for the routine testing of the genetic diversity and purity of accessions held in germplasm collections (Gilbert et al., 1999). Genetic diversity is the basis for genetic improvement. Information regarding the available germplasm is vital to devise efficient plant breeding programs as well as to maintain genetic diversity in a given gene pool. Genetic diversity can be estimated using morphological, biochemical and DNA based markers. Morphological markers are often influenced by prevailing environmental conditions. Molecular markers, based on the polymerase chain reaction (PCR) technique, are the most commonly used for these purposes, several PCR -based techniques have been developed during the last two decades, each with specific advantages and disadvantages. Inter-simple sequence repeat (ISSR) markers permit detection of polymorphisms in inter- microsatellite loci, using a primer designed from dinucleotide or trinucleotide simple sequence repeats.

Egypt. J. Bot., 56, No. 1 (2016) 
ISSR analysis has been successfully documented to determine genetic diversity and relationships in numerous economic legume species such as cow pea (Ajebade et al., 2000), common bean (Gonzales et al., 2005), chickpea (Sudupak, 2004), in addition to faba bean (Terzopoulosa and Bebeli, 2008 and Afiah et al., 2007).

The aims of this investigation are to: (i)_develop genotypes exhibit high yielding under limited-water or saline environments (ii) identify and test ISSRPCR markers for screening five divergent faba bean genotypes which identified drought and salt tolerance under green house experiments, (iii) Estimate the genetic diversity and relationships among these newly breds and released genotypes, (iv) Identify some molecular markers based on ISSR primers associated with the level of drought and salinity tolerance which are detected by using several tolerance indices.

\section{Greenhouse experiments}

\section{Material and Methods}

The five faba bean (Vicia faba L.) genotypes names, pedigree/or selection history and origin are illustrated in Table 1 and Tested in $50 \mathrm{~cm}$. diameter plastic pots, filled with clay soil during winter growing seasons (2011-2012). Five plants were grown in each pot and three pots for each treatment. The two experiments were carried out with split plot design for both drought and salinity stresses.

The first experiment: The soil was irrigated when moisture reached 70, 50 and $30 \%$ of field capacity (FC) using tap water (soil FC was determined on dry weight basis of irrigated pots after keeping saturated soil for $24 \mathrm{hr}$ under free drainage).

_ Irrigation every one week, soil moisture content depleted from $100 \%$ to $70 \%$ of field capacity.

_ Irrigation every two weeks, soil moisture content depleted from $100 \%$ to $50 \%$ of field capacity.

_ Irrigation every three weeks, soil moisture content depleted from $100 \%$ to $30 \%$ of field capacity.

The second experiment: Three concentrations of salt [tap water (control), $30 \mathrm{mM}(1755 \mathrm{ppm})$ and $60 \mathrm{mM}(3510 \mathrm{ppm})]$ in the form of $\mathrm{NaCl}$ were used as irrigation water salinity two weeks after sowing.

\section{Photosynthetic Pigments Extraction and Estimation}

At 45 days after sowing Photosynthetic pigments (chlorophyll $a, b$ and carotenoids) were measured in faba bean leaves after extraction using (JENWAY 6305 UV/VIS) spectrophotometer according to the method described by Lichtenthaler (1987). 
Determination of Total Carbohydrate, Starch and Total soluble sugars

At 45 days after sowing the total carbohydrate content was determined according to Hedge and Hofreiter (1962). Leaf sugar was extracted according to the method described by Angelov et al. (1993) and Total soluble sugar (TSS) were determined using the methods of Riazi et al. (1985). The starch content was estimated by the method prescribed by Hedge and Hofreiter (1962).

\section{Yield and yield attributes}

Number of seeds/pods, number of seeds/plant and seed index were determined for the harvested plants.

TABLE 1. Names, pedigree/or selection history and origin of the five faba bean (Vicia $f a b a$ L.) genotypes tested.

\begin{tabular}{|l|c|c|c|}
\hline \multicolumn{1}{|c|}{ G. } & Name & Pedigree/or selection history & Origin \\
\hline $\begin{array}{l}\text { NBL- } \\
\text { Mar.3 }\end{array}$ & $\begin{array}{c}\text { NBL } \\
\text { (Mar.3) }^{*}\end{array}$ & $\begin{array}{c}\text { ILB1179//(L 3457/3460 W.H.)/ } \\
\text { ( L 3495/3198) }\end{array}$ & Egypt \\
\hline NBL-5 & NBL-5 & G. 716 // A2 / ILB 1179 & Egypt \\
\hline L3 & L3 & A2 / ILB 1179 & ICARDA \\
\hline Nubariya-1 & Nubariya-1 & $\begin{array}{c}\text { An individual plant selection from the } \\
\text { Spain variety Reina Blanka }\end{array}$ & Egypt \\
\hline Misr-1 & Misr-1 & $\begin{array}{l}\text { (G.3x123A/45/76)x(62/1570/66x NBL- } \\
\text { 5)x(Romi x Habashi) }\end{array}$ & Egypt \\
\hline
\end{tabular}

*: $\mathrm{F}_{8}$ Newly bred lines produced through Desert Research Center Legume breeding program

\# : S. Giant (Spain)/ ERESEN-87 (Turkey)

ICARDA ; International Center of Agricultural Research in the Dry Area

\section{ISSR analysis}

For PCR reactions, 10 ISSR primers were used (Table 2). These were carried out in a final volume of $25 \mu \mathrm{L}$, containing $10 \mu \mathrm{g}$ of DNA, $0.5 \mathrm{U}$ Taq polymerase, $2.5 \mu \mathrm{L}$ of $10 \mathrm{X}$ reaction buffer, $3.0 \mathrm{mM} \mathrm{MgCl} 2$ (Kit Inbio Highway), $0.2 \mathrm{mM}$ of each dNTP (Inbio Highway) and $0.8 \mu \mathrm{M}$ primer (Qiagen Operon). DNA amplifications were performed in My Cycler of Bio-Rad thermo cycler, under the following conditions: preliminary step of $10 \mathrm{~min}$ at $94^{\circ} \mathrm{C}$, followed by 40 cycles of $40 \mathrm{sec}$ denaturation at $90^{\circ} \mathrm{C}, 45 \mathrm{sec}$ to annealing temperature by primer (Table 2) and $90 \mathrm{sec}$ extension at $72^{\circ} \mathrm{C}$ with a final $10 \mathrm{~min}$. extension at $72^{\circ} \mathrm{C}$. PCR products were resolved electrophoretically on $2.5 \%$ agarose gels run at $120 \mathrm{~V}$ in TAE $1 \mathrm{X}$ buffer and visualized by staining with Ethidium Bromide $(0.05 \mathrm{mg} / \mathrm{mL})$. Bands were detected on UV-transilluminator and photographed by Gel documentation system Biometra Bio Doc Analyzer 2000.

\section{Statistical analysis}

The experimental design was split plot where, the genotypes arranged in main plots and levels of treatments (water deficit or salinity) were arranged in sub-plots. Both experiments were replicated three times. Data were analyzed as outlined by Snedecor and Cochran (1989). Stress tolerance indices were calculated as shown in Table 3.

Egypt. J. Bot., 56, No. 1 (2016) 
TABLE 2. List of ISSR primers names and their nucleotide sequences.

\begin{tabular}{|c|c|}
\hline Primer code & Sequence(5 $\left.{ }^{\prime}-\mathbf{3}^{\prime}\right)$ \\
\hline HB8 & $(\mathrm{GA})_{6} \mathrm{GG}$ \\
\hline HB10 & $(\mathrm{GA})_{6} \mathrm{CC}$ \\
\hline HB11 & $(\mathrm{GT})_{6} \mathrm{CC}$ \\
\hline HB12 & $(\mathrm{CAC})_{3} \mathrm{GC}$ \\
\hline HB15 & $(\mathrm{GTC})_{3} \mathrm{GC}$ \\
\hline $844 \mathrm{~A}$ & $(\mathrm{CT})_{8} \mathrm{AC}$ \\
\hline $17898 \mathrm{~A}$ & $(\mathrm{CA})_{6} \mathrm{AC}$ \\
\hline $17898 \mathrm{~B}$ & $(\mathrm{CA})_{6} \mathrm{GT}$ \\
\hline $17899 \mathrm{~A}$ & $(\mathrm{CA})_{6} \mathrm{AG}$ \\
\hline $17899 \mathrm{~B}$ & $(\mathrm{CA})_{6} \mathrm{GG}$ \\
\hline
\end{tabular}

TABLE 3. Stress tolerance indices used for evaluation of five divergent faba bean genotypes under each of drought and or salinity environments .

\begin{tabular}{|c|c|c|}
\hline Tolerance indices & Equation & Reference \\
\hline Stress susceptibility index & $\mathbf{S S I}=[1-(Y s / Y p)] /\left[1-\left(\bar{Y}_{S} / \bar{Y}_{p}\right)\right]$ & $\begin{array}{l}\text { Fischer and Maurer } \\
\text { (1978) }\end{array}$ \\
\hline $\begin{array}{l}\text { Stress susceptibility } \\
\text { percentage index }\end{array}$ & $S S P I=\left[(Y p-Y s) / 2\left(\bar{Y}_{p}\right)\right] \times 100$ & Moosavi et al. (2008) \\
\hline Mean productivity & $M P=\left(Y_{s}+Y_{p}\right) / 2$ & $\begin{array}{l}\text { Rosielle and Hambling } \\
\text { (1981) }\end{array}$ \\
\hline Geometric mean productivity & $G M P=\sqrt{(Y s)\left(Y_{p}\right)}$ & $\begin{array}{l}\text { Fernandez (1992) and } \\
\text { Kristin et al. (1997) }\end{array}$ \\
\hline Harmonic mean & $\begin{array}{l}H M=[2(Y p)(Y s)] /[Y p+Y s \\
]\end{array}$ & Jafari et al. (2009) \\
\hline Tolerance index & $T O L=Y p-Y s$ & $\begin{array}{l}\text { Rosielle and Hambling } \\
\text { (1981) }\end{array}$ \\
\hline Stress tolerance index & $S T I=\left(Y_{p}\right)\left(Y_{s}\right) /\left(\bar{Y}_{p}\right)^{2}$ & Fernandez (1992) \\
\hline $\begin{array}{l}\text { Modified stress tolerance } \\
\text { index }\end{array}$ & $\begin{array}{l}M S T I=\mathrm{K}_{\mathrm{i}} \mathrm{STI}, \mathrm{K}_{1}=(Y p)^{2} / \\
\left(\bar{Y}_{p}\right)^{2} \text { and } \mathrm{K}_{2}=(Y s)^{2} /\left(\bar{Y}_{s}\right)^{2}\end{array}$ & $\begin{array}{l}\text { Farshadfar and Sutka } \\
\text { (2002) }\end{array}$ \\
\hline Yield index & $Y I=Y s / \bar{Y}_{S}$ & Gavuzzi et al. (1997) \\
\hline Yield stability index & $Y S I=Y s / Y p$ & $\begin{array}{l}\text { Bouslama and } \\
\text { Schapaugh (1984) }\end{array}$ \\
\hline
\end{tabular}

$Y_{s}$ and $Y_{P}$ are stress and adequate (potential) yield of a given genotype, respectively.

$\bar{Y}_{S}$ and $\bar{Y}_{P}$ are average yield of all genotypes under stress and adequate conditions, respectively. 
Data handling and cluster analysis

ISSR data were scored for computer analysis on the basis of the presence of the amplified products for each primer. If a product is present in a faba bean genotype, it will be designated as " 1 ", if absent, it will be designated as " 0 ", after excluding the unreproducible bands. Pairwise comparisons of all genotypes, based on the presence or absence of unique and shared polymorphic products, was used to determine similarity coefficients, through Jaccard coefficient. The similarity coefficients was used to construct dendograms, using the unweighted Pair Group Method with Arithmetic Averages (UPGMA), employing the SAHN (Sequential, Agglomerative, Hierarchical and Nested clustering) from the NTSYS-PC (Numerical Taxonomy and Multivariate Analysis System), version 2.1 (Applied Biostatistics) program(Rohlf, 2008), the polymorphic information content (PIC) was calculated according to Smith et al.(2000) as follows: PIC $=1-\Sigma^{n}$ fi ${ }^{2}$ where fi is the frequency of the $i^{\text {th }}$ allele in the set of 5 faba bean genotypes.

Genetic similarity among genotypes studied was calculated through Jaccard coefficient, which was recommended to be used for dominant markers ISSR taking in view that the absence of bands, was associated to a homozygous loci. $\mathrm{JC}=\mathrm{a} /(\mathrm{a}+\mathrm{b}+\mathrm{c})$, where $\mathrm{a}, \mathrm{b}, \mathrm{c}$, represented the commons and un-commons of those genotypes (Weising et al., 2005). On the bases of genetic similarity matrix among genotypes, the dendrogram was made using the method of clusters average. Similarity dendrogram was constructed using the UPGMA cluster analysis.

hotosynthetic pigments

Table 4 showes Photosynthetic pigments chlorophyll a and chlorophyll b (mg/g fresh weight) in the leaves of the five faba been genotypes tested under drought and salinity stress levels, respectively. Chlorophyll a ,b and carotenoids content of faba bean leaves genotypes were significantly varied under stress levels(drought and salinity). In all genotypes, the Photosynthetic pigments were higher in control plants than in stressed plants. This appeared that photosynthetic pigments decreased under stress.

Genotypes (NBL- Mar.3) and (NBL-5) had higher values of total chlorophyll content than other genotypes while, genotype (L3) showed the highest values of carotenoids under both drought and salinity stress.

Chlorophyll a , b and total chlorophyll $(\mathrm{a}+\mathrm{b})$ decrease and carotenoids increase were related to both stress (Drought and salinity ) levels. The interaction between genotype(NBL- Mar.3) and drought or salinity gave the highest values of photosynthetic pigments (chlorophyll a,b and total chlorophyll)content of the leaves of faba bean at the first level of both factors. While carotenoids content of genotypes varied in their tolerant to the stress conditions, whereas Nubariya-1 and Misr-1 genotypes were more sensitive to stress conditions than the others.

Egypt. J. Bot., 56, No. 1 (2016) 
It appeared in carotenoids content of the leaves $(10.56 \mathrm{and} 7.08 \mathrm{mg} / \mathrm{g})$ at the first level as a response to the stress treatments. Stressed plants at the first level of both drought and salinity showed higher values of carotenoids content than control plants, This is considered as a good adaptive factor under stress conditions. Maheshwari et al. (2009) have reported that, the increase in carotenoides is one of the adaptive responses that protect chlorophyll and enables plant to complete its life cycle.

The decrease in photosynthetic pigments might have been due to stressinduced increase in the activity of the chlorophyll degrading enzyme, chlorophylase (Reddy et al., 1986) and/or destruction of the chloroplast structure and the instability of pigment protein complexes (Jamil et al., 2012). The higher chlorophyll amounts in tolerant cultivars may be related to their ability in repairing salt-dependent damage. Because of chlorophyll importance as one of necessary factors in plant photosynthesis, it is possible that salt and drought stresses have limited photosynthetic capacity and finally plant yield in Misr-1 and Nubariya-1 cultivar. Therefore, their lower chlorophyll contents can be resulted in their sensitivity and more destruction of photosynthetic pigments in response to salt conditions.

The present results are parallel to Khalafallah et al.(2008) who reported that there is considerable reduction in chlorophyll content in different Vicia faba cultivars due to water deficit and salinity stress. Abdelgawad (2014) found that chlorophyll content in leaves of cowpea decreased under salt stress. The results are also in agreement with Nyachiro et al. (2001), who reported a significant decrease of chlorophyll $\mathrm{a}$ and $\mathrm{b}$ caused by water deficit in six Triticum sativum cultivars.

\section{Total carbohydrates, Total soluble sugars and Starch}

The total carbohydrates and starch have significantly decreased with increasing stress levels (Table 5) in all genotypes. Genotype (NBL-5) and genotype (NBL- Mar.3) recorded the highest values of total carbohydrates under the second level of water deficit $(90.5$ and $77.67 \mathrm{mg} / \mathrm{g}$ dry weight) and salinity stress $(92.3$ and $93.65 \mathrm{mg} / \mathrm{g}$ dry wt.) respectively. On the other hand, significantly increase in the total soluble sugars with increasing the salt and water stress levels in all genotypes, at the second level of water deficit genotype (NBL-5) recorded the highest value $(24.87 \mathrm{mg} / \mathrm{g}$ fresh wt.), where, genotype (Misr-1) recorded the lowest value $(14.50 \mathrm{mg} / \mathrm{g}$ fresh wt.) of total soluble sugar. The increase in the level of total soluble sugar may be linked to the changes in starch content. The second level of stress recorded the highest decrease in total carbohydrate. This is may be due to photosynthesis deficiency which is associated with deterioration in total pigments content while total soluble sugar showed opposite trend, since it was increased significantly and gradually with increasing salinity levels. These results are in agreement with Taie et al. (2013) 
who shows that total carbohydrate in faba bean leaves was negatively affected by salinity stress, and also these results are in harmony with those reported by Maria et al. (2000) who mentioned that salinity stress caused an increase in soluble sugar content with increasing salinity levels while an opposite trend was obtained with respect to polysaccharide concentration. The percentages of increases were more pronounced in in tolerant genotypes (NBL- Mar.3 and NBL-5) than in sensitive genotypes (Nubariya-1 and Misr-1). These results are in agreement with (Cha-um et al., 2009) who stated that total soluble sugar content in salt-tolerant cultivar was significantly greater than in salt-sensitive plants exposed to salt stress. At $100 \mathrm{mM}$ salt treatment, total soluble sugars in the salt-tolerant variety accumulated to a higher level than in salt susceptible (Nemati et al., 2011). The increasing of total soluble sugars in shoots may function as an osmotic adjustment to prevent water loss in the plant cells during salt stress (Siringam et al., 2011).

The role of sugars during environmental stress is that they may function as nutrients which make plants survive under stress. The accumulation of soluble sugars compounds protects the cell under stress by harmonizing the osmotic strength of the cytosol with that of the vacuole and the external environment. The compounds also interact with cellular macromolecules as enzymes and stabilize their structure El-Tayeb (2006).

\section{Yield and yield attributes}

Mean performance of number of seeds/ pod, number of seeds/ plant and seed index under the water deficit and salinity levels are illustrated in Table 6. Under the adequate water ( $30 \%$ of FC) level NBL- 5 was the best genotype and so, it was the most tolerant one as it gave the highest number of seeds/plant followed by NBL- Mar.3 with insignificant difference. While, NBL- Mar.3 had the best number of seeds/plant under both control or highly salt stress $(60 \mathrm{mM})$ treatment. It noteworthy that Nubariya-1 gave the best seed index for all cases studied under either drought or salt stress.

Seed yield /plant showed a wide range of differences among all genotypes in each of the two a biotic stresses in focus. This reflect a fluctuation response in each of the eleven tolerance indices as shown in Table 7. For the effect of water deficit levels, although NBL-5 exhibited the second rank under adequate level ( $30 \%$ of FC) it ranks first under the highest stress level. This confirmed by detecting the lowest values of SSI and TOL indices as well as the highest values of STI, k2STI and YSI for NBL-5. Therefore, NBL-5 could be considered as the highest drought tolerant genotype while Misr-1 is the most sensitive one. Similar conclusion is true for NBL- Mar.3 as a best tolerant genotype under salinity experiment conditions while, Nubariya-1 and Misr-1 were the most sensitive one.

Egypt. J. Bot., 56, No. 1 (2016) 
SALT AND WATER DEFICIT TOLERANCE IN SOME VICIA FABA L. . . 129

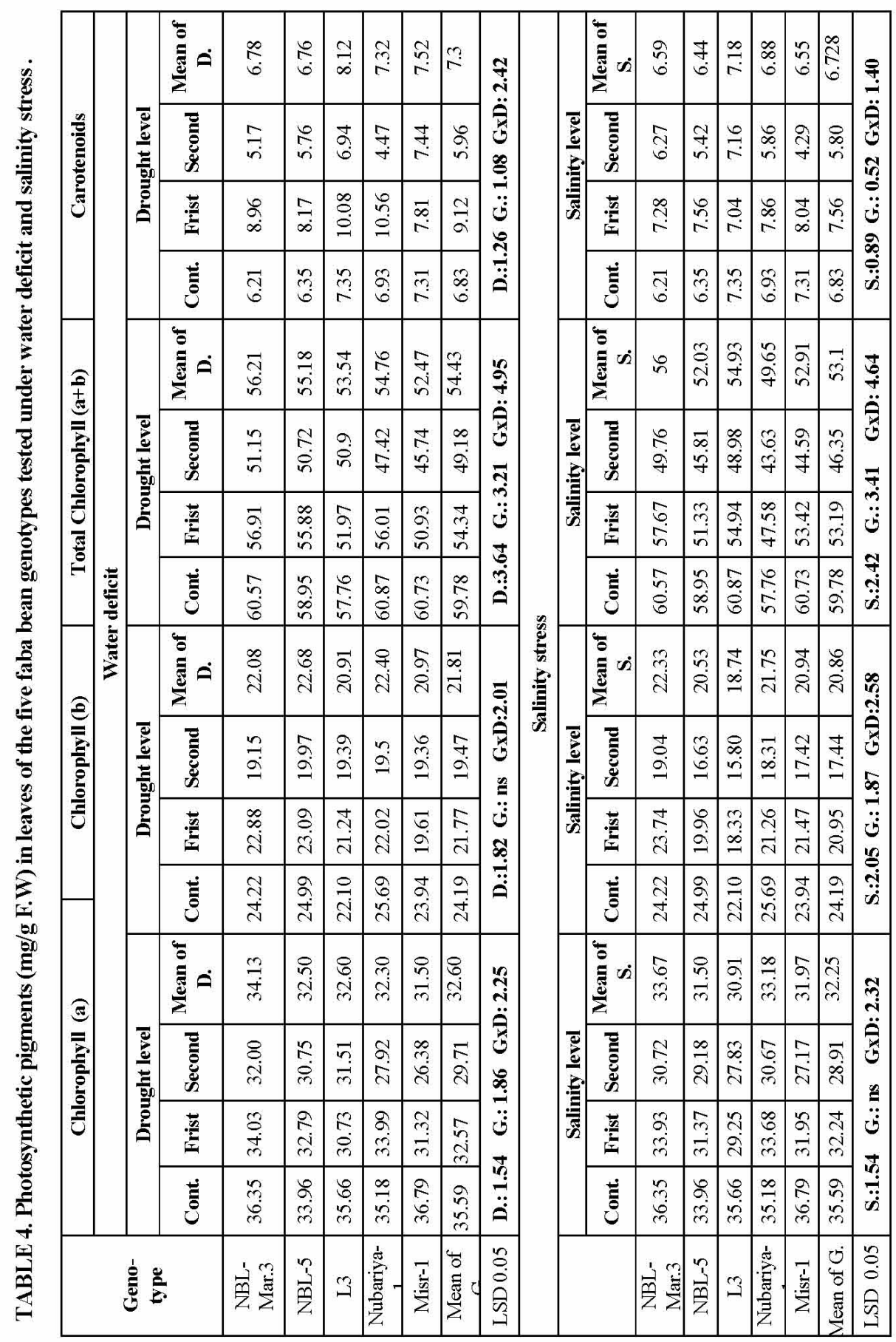

Egypt. J. Bot., 56, No. 1 (2016) 


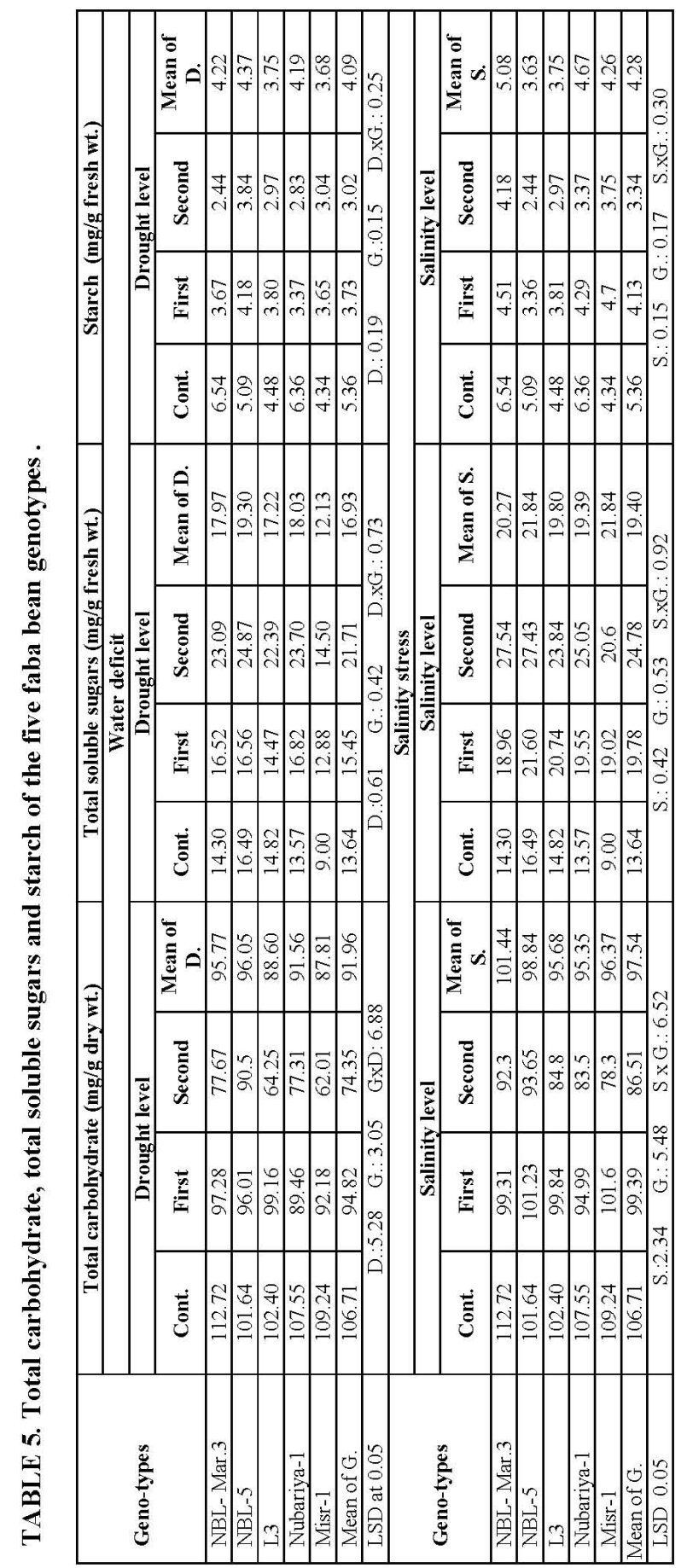

Egypt. J. Bot., 56, No. 1 (2016) 
SALT AND WATER DEFICIT TOLERANCE IN SOME VICIA FABA L. ... 131

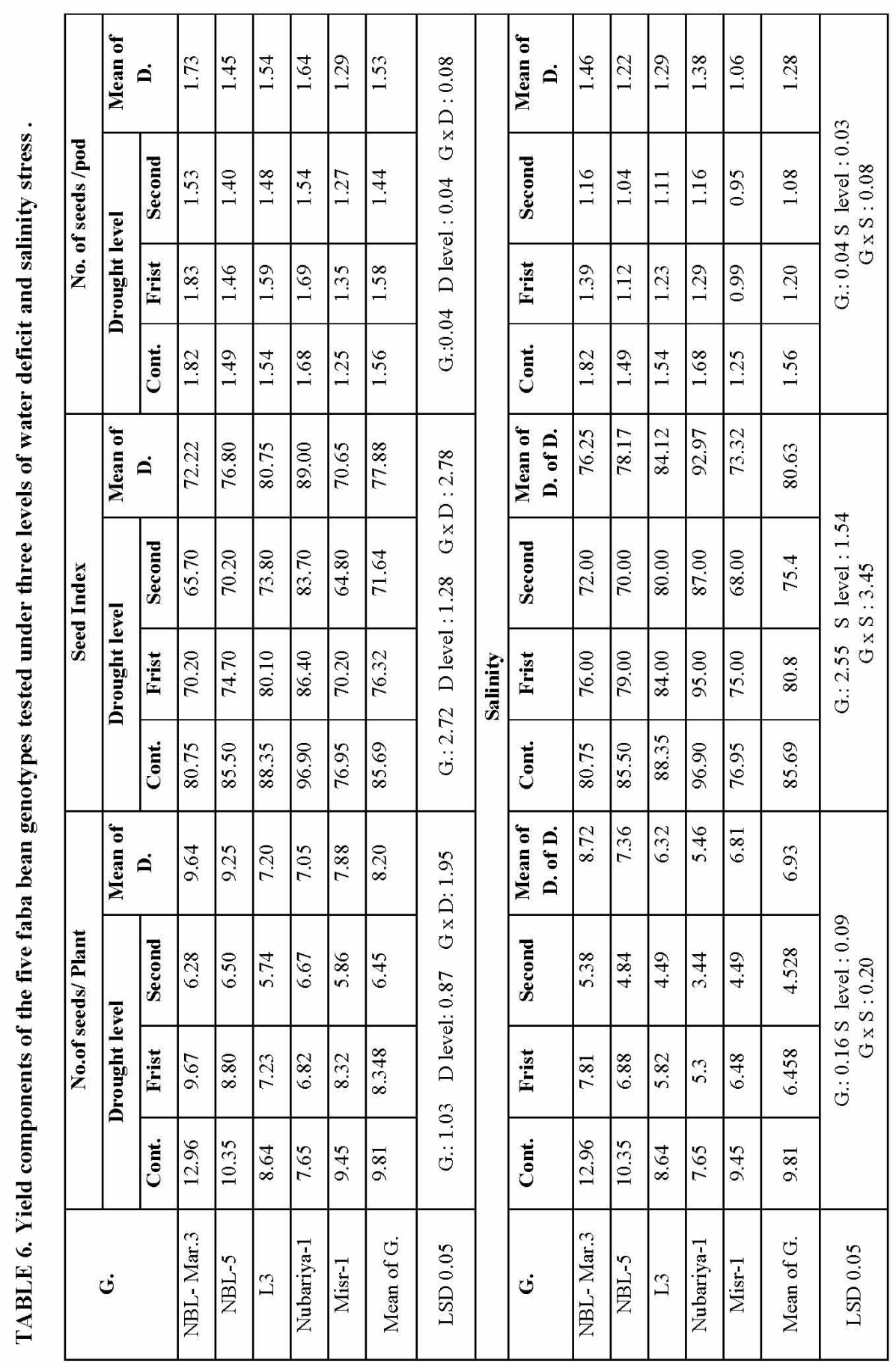

Egypt. J. Bot., 56, No. 1 (2016) 


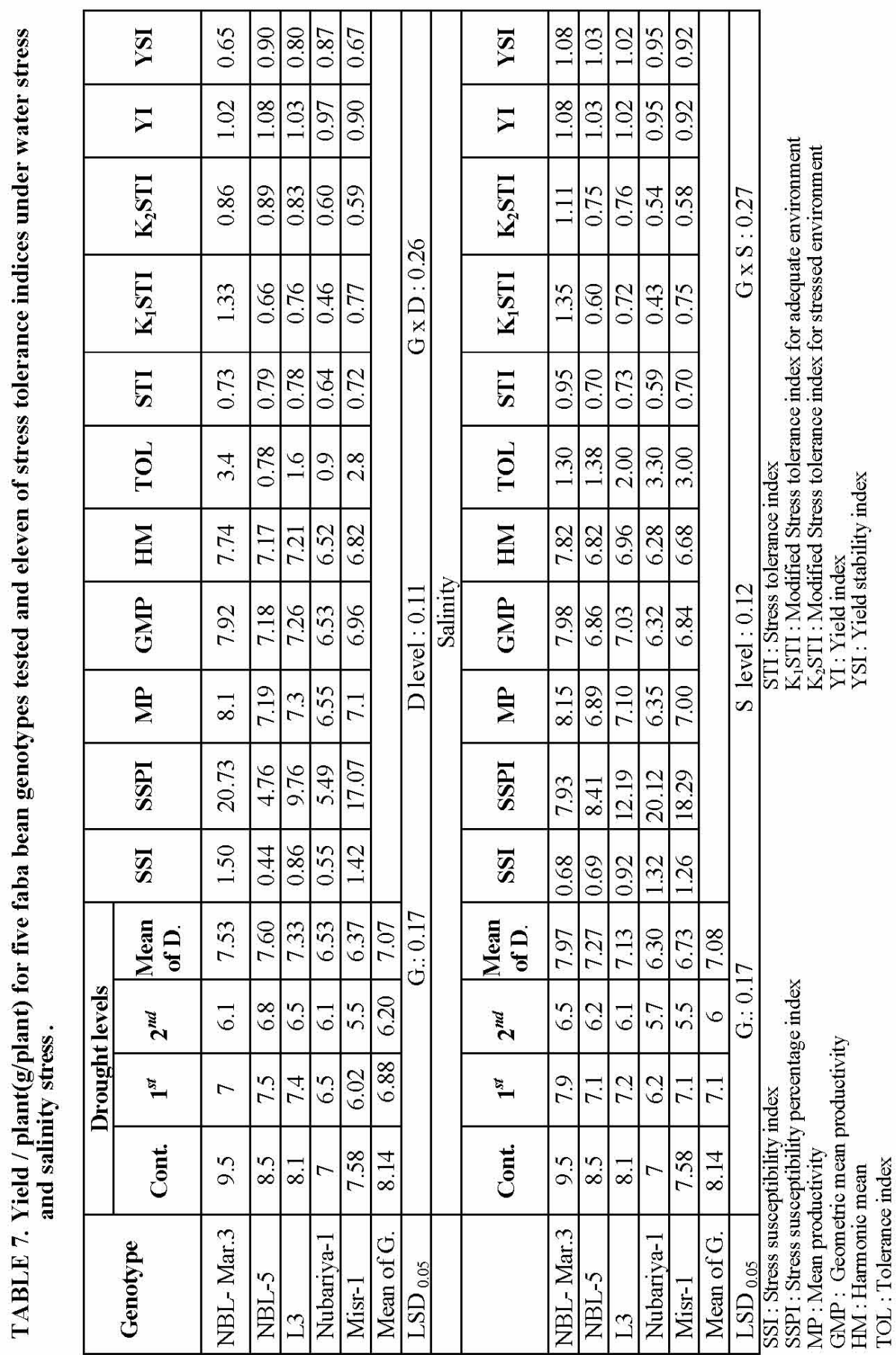

Egypt. J. Bot., 56, No. 1 (2016) 
The less numerical rate of SSI indicates less stress susceptibility and more stress tolerance of a genotype. Yadav and Bhatnagar (2001) suggested the use of SSI in combination with yield value under stressed condition for identifying drought tolerant/susceptible genotypes. Considering TOL index, a genotype would be more tolerant if it has less TOL value. Rosielle and Hambling (1981) has been manifested that TOL index was efficient in improving yield under stressed condition and the selected genotypes performed poorly under adequate conditions. The genotypes with high YSI is expected to have high yield under high stressed and low yield under low-stressed conditions. Fernandez (1992) proposed STI index which discriminates genotypes with high yield and stress tolerance potentials. A high STI demonstrates a high tolerance. This investigation suggested that results of GMP, MP, HM and YI indices in selection of genotypes were similar to STI index.

\section{Inter Simple Sequence Repeat (ISSR-PCR)}

The number of amplicons per primer varied from six (HB12) to 17(844A). The size of the amplified fragments ranged from 200 bp (AF14 and AF67) to 1700bp (AF39). High number of monomorphic amplicons (Three) was scored for $\mathrm{HB} 10$ and 17899B primers (Table 8). These results are in agreement with $\mathrm{Wu}$ et al. (2004) and Afiah et al. (2013) who suggested that ISSR has been used for genetic diversity analysis and obtaining high polymorphism and good molecular markers to discriminating

divergent genotypes.

Characterization of the five faba bean genotypes tested based on ISSR analysis

For ISSR analysis, DNAs of the five selected promising Vicia faba genotypes according to their yielding performance Nubaria 1 and Misr 2 as sensitive genotypes, L.3 as moderate tolerant genotypes and the newly bred lines NBL- Mar.3 and NBL-5 as tolerant one's were subjected to PCR against ten ISSR Primers (HB8, HB10, HB11, HB12, HB15, 844 A, 17898 A, $17898 \mathrm{~B}, 17899 \mathrm{~A}$ and $17899 \mathrm{~B})$ as illustrated in Fig. 1 and presented in Tables 9 and 10.

A total of 99 amplicons (amplified fragments) were generated by the ten primers, out of them 82 were polymorphic (about $80.04 \%$ ) and could be used as genotypic specific markers, were arranged descending as primer 844A (8 total specific markers), primer 17898B (7 markers), primer 17899B (5 markers), primers ISSR HB11(4 markers) and primers 17898A, HB8, HB15 and primer 17899A ( 3 markers), two primers HB10 and HB12 (2 markers).

Primer HB8 produced 7 bands in which fragment sizes ranged from 1000 to $340 \mathrm{bp}, 6$ of which were polymorphic (85.7\% polymorphism). Primer HB10 produced 7 bands in which fragment sized ranged from 1000 to $200 \mathrm{bp}$, four of them were polymorphic. Primer HB11 produced 10 bands with fragment sizes 
ranged from 1200 to $280 \mathrm{bp}$. Primer HB12 yielded 6 bands with the fragment sizes ranged from 850 to $250 \mathrm{bp}, 4$ of them were polymorphic $(66.67 \%$ polymorphism). The primer HB15 revealed 8 bands, out of them 7 were polymorphic.

Concerning the molecular markers, four primers (HB 11, 844A, 17898B and 17899 B) discriminated the highest seed index genotype (Nubaria - 1, Nubaria Nubariya-1) by five positive markers at $\operatorname{AF}(16,48,71,89$ and 90) and two negative specific markers at AF (17 and 96) as shown in (Table-8). The sensitive genotype (Misr-1) for each of the two a biotic stresses tested discriminated by nine unique bands; five positive fragments at $\mathrm{AF}(2,8,34,68$ and 70) and four negative amplicons at $\mathrm{AF}(38,79,80$ and 84). The highest water deficit newly bred tolerant genotype (NBL-5) discriminated by either positive specific markers at $\mathrm{AF}$ (45 and 61) or three negative amplicons at $\mathrm{AF}$ (30, 32 and 33) as illustrated in (Table-8). The salt tolerant genotype (NBL- Mar.3) own ten of the unique amplicons out of the 40 total number specific markers (TSM) which including either the presence or absence of a given band. These bands are summarized in (Table-9). These specific markers could be successfully used as marker assisted selection (MAS) for the best genotypes utilizing in faba bean breeding programs. Many reports previously developed ISSR markers for different characteristics in Vicia faba L. (Abdel-Razzak et al. (2012), Terzopoulosa et al. (2008)).

Based on ISSR marker polymorphisms, similarity matrix was developed by NTSys computer package is shown in Table 10. The analysis was based on the number of markers that were different between any given pair of genotypes. The percentage of similarity between the studied genotypes revealed that, the maximum value of similarity is $82.8 \%$ observed between NBL- Mar.3 and NBL-5 genotypes, whereas the minimum value is $67.1 \%$ observed between NBL- Mar.3 and Misr-1 genotypes. Similar results were reported by Kroth et al. (2005), Brantestam et al. (2007), Afiah et al. (2010) and Afiah et al. (2013) .

The Dendrogram Fig. 2 classified the five faba bean genotypes into two main clusters. The first cluster comprised the two newly bred lines (NBLMar.3 and NBL-5). The second cluster was separated into two sub-clusters comprised the first involved L3 and Nubariya-1 faba bean genotypes while the second sub-cluster separated Misr-1 as a dissimilar one with all other genotypes tested. It worthy to note that, the two newly bred lines (NBLMar.3 and NBL-5) involved in one of their ancestors hence, this may confirm the highest similarity value between them. These findings are in harmony with those previously reported by El-Halfawy et al. (2006), Afiah et al. (2007) and Afiah et al. (2013).

Egypt. J. Bot., 56, No. 1 (2016) 

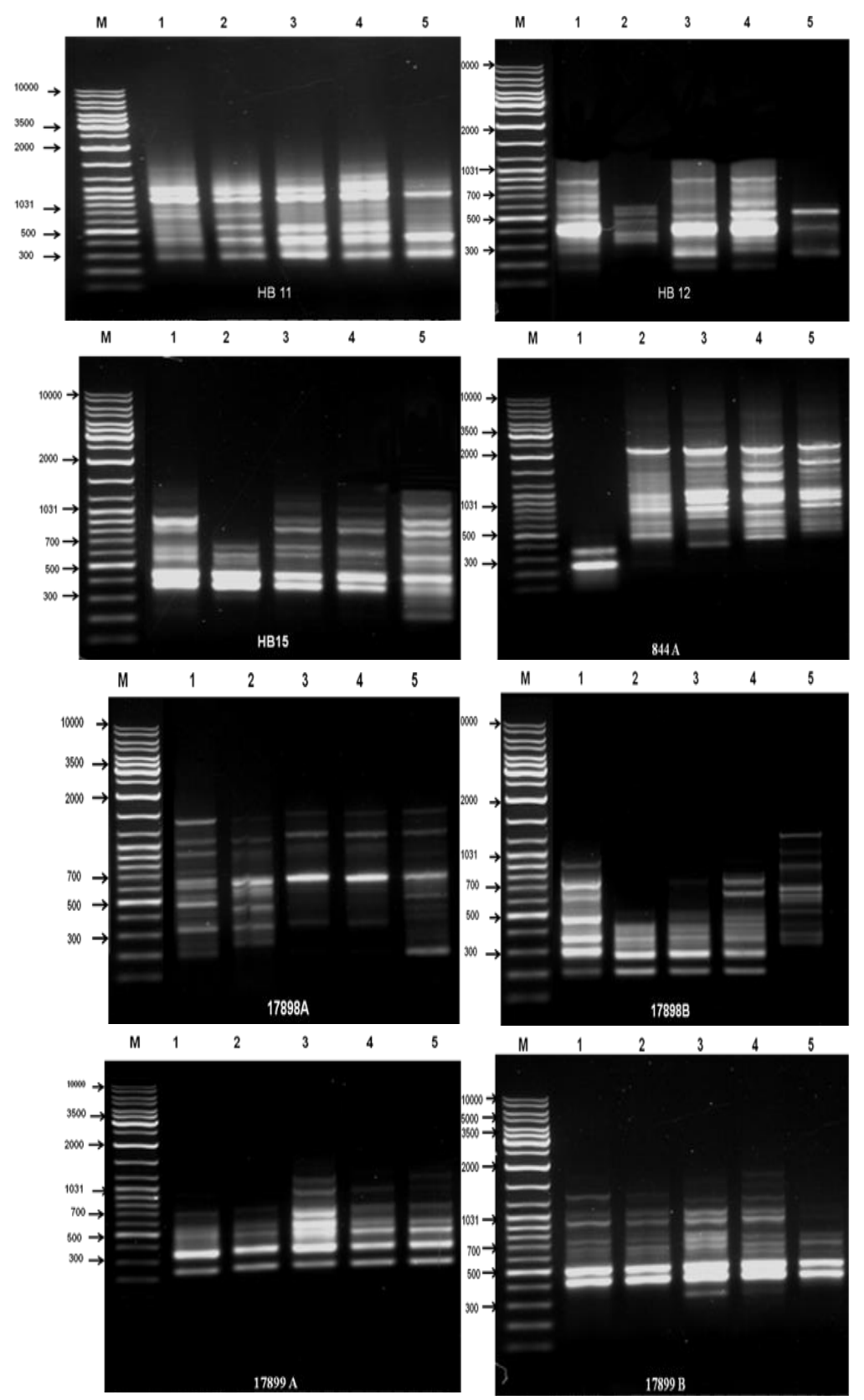

Fig.1. ISSR fingerprints of the five faba bean genotypes tested using ten effective primers.

Lane M: Molecular marker, Lanes 1-5: the 5 genotypes tested (as shown in table 1) 
TABLE 8. ISSR polymorphism in five faba bean genotypes tested using ISSR-PCR with ten primers.

\begin{tabular}{|c|c|c|c|c|c|c|c|c|}
\hline Primer & Amplicon & Bp & $\begin{array}{l}\text { NBL- } \\
\text { Mar.3 }\end{array}$ & NBL-5 & $\mathbf{L 3}$ & Nubariya-1 & Misr-1 & $\mathbf{M}$ \\
\hline \multirow{7}{*}{ HB 8} & AF01 & 1000 & 0 & 0 & 1 & 1 & 1 & \\
\hline & AF02 & 800 & 0 & 0 & 0 & 0 & 1 & $\mathrm{M}^{+}$ \\
\hline & AF03 & 720 & 0 & 0 & 1 & 1 & 0 & \\
\hline & AF04 & 600 & 0 & 1 & 0 & 1 & 0 & \\
\hline & AF05 & 480 & 1 & 1 & 1 & 1 & 1 & \\
\hline & AF06 & 400 & 0 & 0 & 1 & 0 & 0 & $\mathrm{M}^{+}$ \\
\hline & AF07 & 340 & 0 & 0 & 1 & 0 & 0 & $\mathrm{M}^{+}$ \\
\hline \multirow{7}{*}{ HB 10} & AF08 & 1000 & 0 & 0 & 0 & 0 & 1 & $\mathrm{M}^{+}$ \\
\hline & AF09 & 820 & 1 & 1 & 1 & 1 & 1 & \\
\hline & AF10 & 700 & 1 & 1 & 1 & 1 & 1 & \\
\hline & AF11 & 500 & 1 & 1 & 0 & 1 & 0 & \\
\hline & AF12 & 400 & 0 & 1 & 1 & 0 & 0 & \\
\hline & AF13 & 300 & 1 & 1 & 0 & 1 & 1 & $\mathrm{M}^{-}$ \\
\hline & AF14 & 200 & 1 & 1 & 1 & 1 & 1 & \\
\hline \multirow{10}{*}{ HB 11} & AF15 & 1200 & 0 & 0 & 1 & 1 & 0 & \\
\hline & AF16 & 1120 & 0 & 0 & 0 & 1 & 0 & $\mathrm{M}^{+}$ \\
\hline & AF17 & 1000 & 1 & 1 & 1 & 0 & 1 & $\mathrm{M}^{-}$ \\
\hline & AF18 & 850 & 1 & 1 & 1 & 1 & 1 & \\
\hline & AF19 & 700 & 1 & 0 & 0 & 1 & 0 & \\
\hline & AF20 & 640 & 1 & 1 & 0 & 0 & 0 & \\
\hline & AF21 & 500 & 1 & 1 & 1 & 1 & 0 & $\mathrm{M}^{-}$ \\
\hline & AF22 & 410 & 1 & 1 & 1 & 1 & 0 & $\mathrm{M}^{-}$ \\
\hline & AF23 & 360 & 1 & 1 & 0 & 0 & 0 & \\
\hline & AF24 & 280 & 1 & 1 & 1 & 1 & 1 & \\
\hline \multirow{6}{*}{ HB 12} & AF25 & 850 & 1 & 0 & 1 & 1 & 0 & \\
\hline & AF26 & 700 & 1 & 0 & 0 & 0 & 0 & $\mathrm{M}^{+}$ \\
\hline & AF27 & 620 & 1 & 0 & 1 & 1 & 0 & \\
\hline & AF28 & 500 & 1 & 1 & 1 & 1 & 1 & \\
\hline & AF29 & 380 & 1 & 1 & 1 & 1 & 1 & \\
\hline & AF30 & 250 & 1 & 0 & 1 & 1 & 1 & $\mathrm{M}^{-}$ \\
\hline \multirow{8}{*}{ HB 15} & AF31 & 1080 & 0 & 0 & 0 & 0 & 1 & \\
\hline & AF32 & 900 & 1 & 0 & 1 & 1 & 1 & $\mathrm{M}^{-}$ \\
\hline & AF33 & 800 & 1 & 0 & 1 & 1 & 1 & $\mathrm{M}^{-}$ \\
\hline & AF34 & 690 & 0 & 0 & 0 & 0 & 1 & $\mathrm{M}^{+}$ \\
\hline & AF35 & 640 & 1 & 1 & 1 & 0 & 0 & \\
\hline & AF36 & 500 & 0 & 1 & 0 & 1 & 0 & \\
\hline & AF37 & 420 & 1 & 1 & 1 & 1 & 1 & \\
\hline & AF38 & 370 & 1 & 1 & 1 & 1 & 0 & $\mathrm{M}^{-}$ \\
\hline
\end{tabular}

Egypt. J. Bot., 56, No. 1 (2016) 
SALT AND WATER DEFICIT TOLERANCE IN SOME VICIA FABA L. .. 137

TABLE 8 . Cont.

\begin{tabular}{|c|c|c|c|c|c|c|c|c|}
\hline Primer & Amplicon & $\mathbf{B p}$ & $\begin{array}{l}\text { NBL- } \\
\text { Mar.3 }\end{array}$ & NBL-5 & $\mathbf{L 3}$ & Nubariya-1 & Misr-1 & $\mathbf{M}$ \\
\hline \multirow{17}{*}{$844 \mathrm{~A}$} & AF39 & 1700 & 0 & 1 & 1 & 1 & 1 & $\mathrm{M}^{-}$ \\
\hline & AF40 & 1530 & 0 & 0 & 1 & 1 & 1 & \\
\hline & AF41 & 1380 & 0 & 0 & 1 & 0 & 1 & \\
\hline & AF42 & 1300 & 0 & 0 & 0 & 1 & 0 & \\
\hline & AF43 & 1210 & 0 & 0 & 1 & 0 & 1 & \\
\hline & AF44 & 1050 & 0 & 0 & 1 & 1 & 1 & \\
\hline & AF45 & 1000 & 0 & 1 & 0 & 0 & 0 & $\mathrm{M}^{+}$ \\
\hline & AF46 & 900 & 0 & 0 & 1 & 1 & 1 & \\
\hline & AF47 & 810 & 0 & 1 & 1 & 0 & 1 & \\
\hline & AF48 & 740 & 0 & 0 & 0 & 1 & 0 & $\mathrm{M}^{+}$ \\
\hline & AF49 & 680 & 0 & 0 & 1 & 0 & 0 & $\mathrm{M}^{+}$ \\
\hline & AF50 & 600 & 0 & 1 & 1 & 1 & 1 & $\mathrm{M}^{-}$ \\
\hline & AF51 & 550 & 0 & 1 & 1 & 0 & 1 & \\
\hline & AF52 & 480 & 0 & 1 & 0 & 1 & 0 & \\
\hline & AF53 & 410 & 0 & 0 & 1 & 0 & 0 & $\mathrm{M}^{+}$ \\
\hline & AF54 & 320 & 1 & 0 & 0 & 0 & 0 & $\mathrm{M}^{+}$ \\
\hline & AF55 & 250 & 1 & 0 & 0 & 0 & 0 & $\mathrm{M}^{+}$ \\
\hline \multirow{12}{*}{$17898 \mathrm{~A}$} & AF56 & 1350 & 1 & 0 & 0 & 0 & 0 & $\mathrm{M}^{+}$ \\
\hline & AF57 & 1040 & 1 & 1 & 1 & 1 & 1 & \\
\hline & AF58 & 910 & 1 & 1 & 1 & 1 & 0 & \\
\hline & AF59 & 720 & 1 & 0 & 0 & 0 & 0 & $\mathrm{M}^{+}$ \\
\hline & AF60 & 640 & 1 & 1 & 1 & 1 & 1 & \\
\hline & AF61 & 550 & 0 & 1 & 0 & 0 & 0 & $\mathrm{M}^{+}$ \\
\hline & AF62 & 500 & 1 & 1 & 0 & 0 & 0 & \\
\hline & AF63 & 460 & 1 & 1 & 0 & 0 & 1 & \\
\hline & AF64 & 400 & 1 & 0 & 0 & 0 & 1 & \\
\hline & AF65 & 320 & 1 & 1 & 0 & 0 & 0 & \\
\hline & AF66 & 240 & 1 & 1 & 0 & 0 & 0 & \\
\hline & AF67 & 200 & 1 & 0 & 0 & 0 & 1 & \\
\hline \multirow{13}{*}{$17898 \mathrm{~B}$} & AF68 & 1210 & 0 & 0 & 0 & 0 & 1 & $\mathrm{M}^{+}$ \\
\hline & AF69 & 900 & 1 & 0 & 0 & 0 & 0 & $\mathrm{M}^{+}$ \\
\hline & AF70 & 860 & 0 & 0 & 0 & 0 & 1 & $\mathrm{M}^{+}$ \\
\hline & AF71 & 760 & 0 & 0 & 0 & 1 & 0 & $\mathrm{M}^{+}$ \\
\hline & AF72 & 700 & 1 & 0 & 0 & 0 & 1 & \\
\hline & AF73 & 650 & 0 & 0 & 0 & 1 & 1 & \\
\hline & AF74 & 610 & 1 & 0 & 0 & 0 & 1 & \\
\hline & AF75 & 550 & 0 & 0 & 0 & 0 & 1 & \\
\hline & AF76 & 480 & 1 & 0 & 1 & 1 & 0 & \\
\hline & AF77 & 390 & 0 & 1 & 1 & 1 & 1 & $\mathrm{M}^{-}$ \\
\hline & AF78 & 350 & 1 & 1 & 1 & 1 & 1 & \\
\hline & AF79 & 290 & 1 & 1 & 1 & 1 & 0 & $\mathrm{M}^{-}$ \\
\hline & AF80 & 240 & 1 & 1 & 1 & 1 & 0 & $\mathrm{M}^{-}$ \\
\hline
\end{tabular}

Egypt. J. Bot., 56, No. 1 (2016) 
TABLE 8 . Cont.

\begin{tabular}{|c|c|c|c|c|c|c|c|c|}
\hline Primer & Amplicon & Bp & $\begin{array}{l}\text { NBL- } \\
\text { Mar.3 }\end{array}$ & $\begin{array}{c}\text { NBL- } \\
5\end{array}$ & $\mathbf{L 3}$ & Nubariya- & Misr-1 & $\mathbf{M}$ \\
\hline \multirow{8}{*}{$\begin{array}{c}17899 \\
\text { A }\end{array}$} & AF81 & 1080 & 0 & 0 & 1 & 0 & 0 & $\mathrm{M}^{-}$ \\
\hline & AF82 & 950 & 0 & 0 & 1 & 0 & 0 & $\mathrm{M}^{+}$ \\
\hline & AF83 & 800 & 0 & 0 & 0 & 1 & 1 & \\
\hline & \begin{tabular}{|l|} 
AF84 \\
\end{tabular} & 730 & 1 & 1 & 1 & 1 & 0 & $\mathrm{M}$ \\
\hline & AF85 & 650 & 0 & 0 & 1 & 1 & 1 & \\
\hline & AF86 & 500 & 1 & 1 & 1 & 0 & 0 & \\
\hline & \begin{tabular}{|l|} 
AF87 \\
\end{tabular} & 360 & 1 & 1 & 1 & 1 & 1 & \\
\hline & AF88 & 250 & 1 & 1 & 1 & 1 & 1 & \\
\hline \multirow{11}{*}{$\begin{array}{c}17899 \\
\text { B }\end{array}$} & AF89 & 1650 & 0 & 0 & 0 & 1 & 0 & $\mathrm{M}^{\top}$ \\
\hline & AF90 & 1500 & 0 & 0 & 0 & 1 & 0 & $\mathrm{M}^{\top}$ \\
\hline & AF91 & 1400 & 1 & 1 & 0 & 0 & 0 & \\
\hline & AF92 & 1320 & 0 & 0 & 1 & 1 & 0 & \\
\hline & AF93 & 1050 & 1 & 0 & 0 & 0 & 0 & $\mathrm{M}^{+}$ \\
\hline & \begin{tabular}{|l|} 
AF94 \\
\end{tabular} & 980 & 1 & 1 & 1 & 1 & 1 & \\
\hline & AF95 & 800 & 0 & 0 & 1 & 1 & 1 & \\
\hline & AF96 & 740 & 1 & 1 & 1 & 0 & 1 & $\mathrm{M}$ \\
\hline & AF97 & 500 & 1 & 1 & 1 & 1 & 1 & \\
\hline & \begin{tabular}{|l|} 
AF98 \\
\end{tabular} & 410 & 1 & 1 & 1 & 1 & 1 & \\
\hline & AF99 & 350 & 0 & 0 & 1 & 0 & 0 & $\mathrm{M}^{-}$ \\
\hline
\end{tabular}

$\mathrm{M}^{-}$: Negative molecular marker

$\mathrm{M}^{+}$: Positive molecular marker

TABLE 9. Amplification results of the ten ISSR primers for the five Vicia faba L. genotypes tested.

\begin{tabular}{|c|c|c|c|c|c|c|c|c|c|c|c|c|c|c|}
\hline \multirow{3}{*}{ Primers } & \multirow{3}{*}{ TAF } & \multirow{3}{*}{ PB } & \multirow{3}{*}{ P\% } & \multicolumn{10}{|c|}{ Genotypes } & \multirow{3}{*}{ TSM } \\
\hline & & & & \multicolumn{2}{|c|}{$\begin{array}{l}\text { NBL- } \\
\text { Mar.3 }\end{array}$} & \multicolumn{2}{|c|}{ NBL-5 } & \multicolumn{2}{|c|}{ L3 } & \multicolumn{2}{|c|}{\begin{tabular}{|c} 
Nubariy \\
a-1
\end{tabular}} & \multicolumn{2}{|c|}{ Misr-1 } & \\
\hline & & & & AF & SM & $\overline{\mathbf{A F}}$ & SM & $\overline{\mathbf{A F}}$ & SM & AF & SM & $\mathbf{A F}$ & SM & \\
\hline HB 8 & 7 & 6 & 85.70 & 1 & 0 & 2 & 0 & 5 & 2 & 4 & 0 & 3 & 1 & 3 \\
\hline HB 10 & 7 & 4 & 57.14 & 5 & 0 & 6 & 0 & 4 & 1 & 5 & 0 & 5 & 1 & 2 \\
\hline HB 11 & 10 & 8 & 80.0 & 8 & 0 & 7 & 0 & 6 & 0 & 7 & 2 & 3 & 2 & 4 \\
\hline HB12 & 6 & 4 & 66.67 & 6 & 1 & 2 & 1 & 5 & 0 & 5 & 0 & 3 & 0 & 2 \\
\hline HB 15 & 8 & 7 & 87.50 & 5 & 0 & 4 & 2 & 5 & 0 & 5 & 0 & 5 & 2 & 4 \\
\hline $844 \mathrm{~A}$ & 17 & 17 & 100.0 & 2 & 4 & 6 & 1 & 11 & 2 & 8 & 1 & 9 & 0 & 8 \\
\hline $17898 \mathrm{~A}$ & 12 & 10 & 83.33 & 11 & 2 & 8 & 1 & 3 & 0 & 3 & 0 & 5 & 0 & 3 \\
\hline $17898 \mathrm{~B}$ & 13 & 12 & 92.31 & 7 & 2 & 4 & 0 & 5 & 0 & 7 & 1 & 8 & 4 & 7 \\
\hline $17899 \mathrm{~A}$ & 8 & 6 & 75.00 & 4 & 0 & 4 & 0 & 7 & 2 & 5 & 0 & 4 & 1 & 3 \\
\hline $17899 \mathrm{~B}$ & 11 & 8 & 72.73 & 6 & 1 & 5 & 0 & 7 & 1 & 7 & 3 & 5 & 0 & 5 \\
\hline Total & 99 & 82 & 80.04 & 55 & 10 & 48 & 5 & 58 & 8 & 56 & 7 & 50 & 11 & 41 \\
\hline
\end{tabular}

$\mathrm{TAF}=$ Total number of amplified fragments, $\mathrm{PB}=$ Polymorphic bands, $\mathrm{P} \%=$ Polymorphism percentage, $\mathrm{AF}=$ Amplified fragments / genotype, $\mathrm{SM}=$ Genotype- specific marker including either the presence or absence of a given band, TSM= Total number of specific markers.

Egypt. J. Bot., 56, No. 1 (2016) 
TABLE 10 . Similarity matrix among the five faba bean genotypes tested based on ten ISSR -PCR primers analysis.

\begin{tabular}{|c|c|c|c|c|}
\hline Genotype & $\mathbf{1}$ & $\mathbf{2}$ & $\mathbf{3}$ & $\mathbf{4}$ \\
\hline 2 & 0.828 & & $\cdot$ & \\
\hline 3 & 0.706 & 0.762 & & \\
\hline 4 & 0.706 & 0.747 & 0.821 & \\
\hline 5 & 0.671 & 0.697 & 0.762 & 0.731 \\
\hline
\end{tabular}

$\begin{array}{llllll}0.60 & 0.65 & 0.70 & 0.75 & 0.80 & 0.85\end{array}$
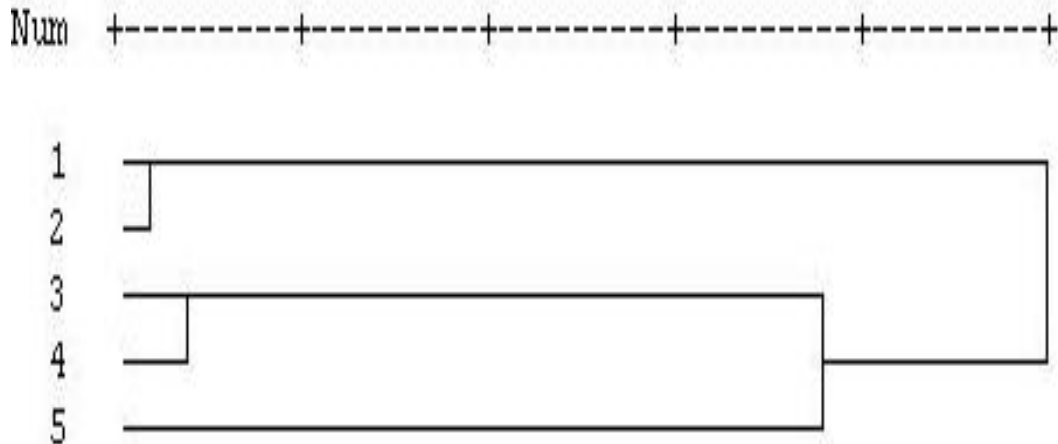

Fig. 2 . Genetic distance among the five faba bean genotypes tested using NTSys (V.2.1) program based on ten ISSR -PCR primers analysis.

\section{References}

Abdelgawad, Z.A. (2014) Improving growth and yield of salt-stressed cowpea plants by exogenous application of ascobin. Life Sci. J. , 11(11): 43-51.

Abdel-Razzak, H. S., Alfrmawy, A. M. Ibrahim, H. M. and Amr, A. El-Hanafy (2012) Genetic diversity in faba bean (Vicia faba L.) using inter-simple sequence repeat (ISSR) marker protein analysis. Life Science Journal, 9 (2): 497-503.

Afiah, S. A., Abdelsalam, A. Z. E. and Abdel-Gawad, Z.A. (2007) Bulked segregant analysis for developing genetic markers of drought tolerance in faba bean (Vicia faba L.). Egyptian Journal of Desert Research, 57 (1): 89-112.

Afiah, S.A., Farag, H.I.A. El-Nahas, A.I. and Akladious, S.A. (2013) Molecular discrimination of some barley genotypes under maryout rainfed condition. $8^{\text {th }}$ plant breeding International Conf. 14-15 May special issue of Egypt. J. Plant Breed., 17(2): 80-98. 
Afiah, S.A., El-Halfawy, K.h. A. Zaki, K.I., Salem, M.F. and Ismail, A. (2010) Selecting barley genotypes for salinity tolerance in the bases of molecular genetic markers. J. Biol. Chem. Environ. Sci., 5 (1): 57-77.

Aguilera, J. G., Pessoni, L.A., Rodrigues, G.B., Elsayed, A.Y., da Silva, D.J. and de Barros, E.G. (2011) Genetic variability by ISSR markers in tomato (Solanum lycopersicon Mill). Revista Brasileira de Ciências Agrárias Recife, 6(2): 243-252.

Ajebade, S. R., Weeden, N.F. and Chite, S.M. (2000) Inter simple sequence repeat analysis of genetic relationships in the genus Vigna. Euphytica, 111(1): 47-55.

Alghamdi, S. S. (2009) Chemical composition of faba bean (Vicia faba L.) genotypes under various water regimes. Pakistan Journal of Nutrition, 8(4): 477-482.

Angelov, M. N., Sun, J., Byrd, G.T., Brown, R.H. and Black, C.C. (1993) Novel characteristics of Cassava, Manihot esculenta Crantz, a reputed C3-C4 intermediate photosynthetic species. Photosynth Res. 38: 61-72.

Bakry, B. A., Elewa, T. A., El karamany, M. F., Zeidan, M. S. and Tawfik, M. M. (2011) Effect of row spacing on yield and its components of some faba bean varieties under newly reclaimed sandy soil condition. World Journal of Agricultural Science, 7(1): 68-72.

Bouslama, M. and Schapaugh, W.T. (1984) Stress tolerance in soybean. Part 1: evaluation of three screening techniques for heat and drought tolerance. Crop Sci., 24: 933-937.

Brantestam, A.K., Bothmer, R.V., Dayteg, C., Rashal, I., Tuvesson, S. and Weibull, J. (2007) Genetic diversity changes and relationships in spring barley (Hordeum vulgare L.) germplasm of Nordic and Baltic areas as shown by SSR markers. Genetic Res.and Crop Evolution, 54(4): 749-758.

Cha-um, S., Charoenpanich, A., Roytrakul, S. and Kirdmanee, C. (2009) Sugar accumulation, photosynthesis and growth of two indica rice varieties in response to salt stress. Acta Physiol Plant, 31: 477-486.

Duc, G. (1997) Faba bean (Vicia faba L ). Field Crops Research, 53: 99-109.

El-Halfawy, Kh. A., Afiah, S. A., Zaki, K. I. and Al-Masry, A.I. S. (2006) RAPDMarkers for yield ability and disease resistance in barley under rainfed conditions . Egyptian J. Desert Res., 56 (2): 363-379.

El-Tayeb, M. A. (2006) Differential response of two vicia faba cultivars to drought: growth, pigments, lipid peroxidation, organic solutes, catalase and peroxidase activity. Acta Agronomica Hungarica, 54(1): 25-37.

Farshadfar, E. and Sutka, J. (2002) Multivariate analysis of drought tolerance in wheat substitution lines. Cereal Res. Commun., 31: 33-39. 
Fernandez, G.C.J. (1992) Effective selection criteria for assessing stress tolerance. In: Proceedings of the International Symposium on Adaptation of Vegetables and Other Food Crops in Temperature and Water Stress Tolerance, Asian Vegetable Research and Development Centre, Taiwan, pp. 257-270.

Fischer, R.A. and Maurer, R. (1978) Drought resistance in spring wheat cultivars: I. Grain yield responses. Aust. J. Agric. Res., 29: 897-912.

Gavuzzi, P., Rizza, F., Palumbo, M., Campaline, R. G., Ricciardi, G. L. and Borghi, B. (1997) Evaluation of field and laboratory predictors of drought and heat tolerance in winter cereals. Plant Sci., 77: 523-531.

Gilbert, J. E., Lewis, R. V., Wilkinson, M. J. and Caligari, P. D. S. (1999) Developing an appropriate strategy to assess genetic variability in plant germplasm collections. Theoretical and Applied Genetics, 98: 1125-1131.

Gonzales, A., Delgado-Salinas, W. A., Papa, R. and Gepts, P. (2005) Assessment of inter simple sequence repeat markers to differentiate sympatric wild and domesticated populations of common bean. Crop. Science, 45: 606-615.

Hedge, J. E and Hofreiter, B. T. (1962) In: "Carbohydrate Chemistry", 17 (Eds. R.L. Whistler and J.N. Be Miller,), Academic Press, New York.

Jafari A., Paknejad, F., Jami Al-Ahmadi, M. (2009) Evaluation of selection indices for drought tolerance of corn (Zea mays L.) hybrids. Int. J. Plant. Prot., 3: 33-38.

Jamil, M., Bashir, S., Anwar, S., Bibi, S., Bangash, A., Ullah, F. and Shikrha, E. (2012) Effect of salinity on physiological and biochemical characteristics of different varieties of rice. Pakistan Journal of Botany, 44: 7-13.

Khalafallah, A. A., Tawfik, K. M. and Abd El- Gawad, Z. A. (2008) Tolerance of seven faba bean varieties to drought and salt stresses. Research Journal of Agriculture \& Biological Science, 4(2): 175-186.

Kristin, A.S., Serna, R.R. Pérez, F.I., Enríquez, B.C., Gallegos, J.A.A., Vallejo, P.R., Wassimi, N. and Kelley, J.D. (1997) Improving common bean performance under drought stress. Crop Sci., 37: 43-50.

Kroth, M.A. , Ramella, M.S., Tagliari, C., de Francisco, A. and Arisi, A.C.M. (2005) Genetic similarity of Brazilian hull-less and malting barley varieties evaluated by rapid markers. Sci. Agric. Piracicaba, Braz., 62(1): 36-39.

Lichtenthaler, H.K. (1987) Chlorophylls and carotenoids: pigments of photosynthetic biomembranes. Methods Enzymol., 148: 350-82.

Maria, E.B., José, D.A., Maria, C.B. and Francisco, P.A. (2000) Carbon partitioning and sucrose metabolism in tomato plants growing under salinity. Physiol. Planta., 110: $503-111$

Maheshwari, M., Basant, L. and Grewal, H. S. (2009) Magnetic treatment of irrigation water: Its effects on vegetable crop yield and water. Prod., 8, 1229-1236. 
Moosavi, S.S., Samadi, B.Y., Naghavi, M.R., Zali, A.A., Dashti, H. and Pourshahbazi, A. (2008) Introduction of new indices to identify relative drought tolerance and resistance in wheat genotypes. Desert., 12: 165-178.

Nemati, I., Moradi, F., Gholizadeh, S., Esmaeili, M. A. and Bihamta, M. R. (2011) The effect of salinity stress on ions and soluble sugar a distribution in leaves, leaf sheaths and roots of rice (Oryza sativa L.) seedlings. Plant Soil Environ., 57: 26-33.

Nyachiro, J. M., Briggs, K. J., Hoddinott, J. and Johnson-Flanagan, A. M. (2001) Chlorophyll content, chlorophyll fluorescence and water deficit in spring wheat, Cereal Res. Comm., 29: 135- 142.

Reddy, M.P. and Vora, A.B. (1986) Changes in pigment composition, hill reaction activity and saccharides metabolism in bajra (Pennisetum typhoides $\mathrm{S} \& \mathrm{H}$ ) leaves under $\mathrm{NaCl}$ salinity. Photosynthica, 20: 50-55.

Riazi, A., Matsuda, K. and Arslov, A. (1985) Water stress induccd changes in concentrations of proline and other solutes in growing regions of young barley leaves. J. exp. Bot., 36: 1716-1725.

Rohlf, F. J. (2008) NTSYS. Pc., Version 2.20U, S. Exeter Software etauket, New York.

Rosielle, A. and Hambling, J. (1981) Theoretical aspects of selection for yield in stress and non-stress environment. Crop Sci., 21: 943-946.

Siringam, K., Juntawong, N., Cha-um, S. and Kirdmanee, C. (2011) Salt stress induced ion accumulation, ion homeostasis, membrane injury and sugar contents in salt-sensitive rice (Oryza sativa L. spp. indica) roots under isoosmotic conditions. African Journal of Biotechnology., 10(8):1340-1346.

Snedecor, G.W. and Cochran, W.G. (1989) "Statistical Methods", $8^{\text {th }}$ ed. Iowa State Univ. Press. pp. 298-330.

Sudupak, M. A. (2004) Inter- and intra-species inter simple sequence repeat (ISSR) variation in the genus Cicer. Euphytica, 135: 229-238.

Suresh, S., Park, J.H., Cho, G.T., Lee, H.S., Baek, H.J., Lee, S.Y. and Chung , Jg.W. (2013) Development and molecular characterization of 55 Novel polymorphic cDNA-SSR markers in faba bean (Vicia faba L.) using 454 pyrosequencing. Molecules, 18: 1844-1856.

Taie, H., Abdelhamid, M. T., Dawood, M. G. and Nassar, R. M. (2013) Pre sowing seed treatment with proline improves some physiological, biochemical and anatomical attributes of faba bean plants under sea water stress. J. Appl. Sci. Res., 9: 2853-2867.

Terzopoulosa, P.J. and Bebeli, P. J. (2008) Genetic diversity analysis of mediterranean faba bean (Vicia faba L.) with ISSR markers. Field Crops Research, 108: 39-44.

Toker, C., (2004) Estimates of broad-sense heritability for seed yield and yield criteria in faba bean (Vicia faba L.), Hereditas, 140: 222-225.

Egypt. J. Bot., 56, No. 1 (2016) 
Weising, K., Nybom, H. Wolf, K. and Kahl, G. (2005) "DNA Fingerprinting in Plants: Principles, Methods and Applications". $2^{\text {nd }}$ ed. CRC Press Taylor and Francis Group, Boca Raton, USA.

Wu, C. J., Cheng, Z. Q. Huang, X. Q. Yin, S. H., Cao, K.M. and Sun, C.R. (2004) Genetic diversity among and within populations of Oryza granulata from Yunnan of China revealed by RAPD and ISSR markers: implications for conservation of the endangered species. Plant Science, 167: 35-42.

Yadav O.P. and Bhatnagar, S.K. (2001) Evaluation of indices for identification of pearl millet cultivars adapted to stress and non- stress conditions. Field Crops Res., 70: 201-208.

(Received 2/3/2015; accepted 19/5/2015) 


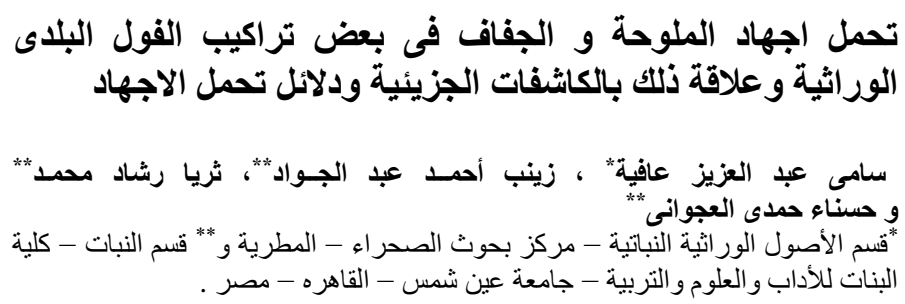

أجرى هذا البحث بهدف دراسة استجابة خمسة تر اكيب ور اثية المتباعدة من الفول البلدى لكل

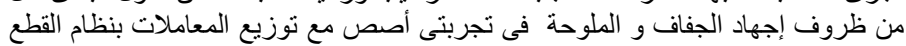
المنشقة مره و واحده لكل منها.

تم تقدير محتوى الكلوروفيل و الكاروتينات وكذلك محتوى الأوراق من الكربو هيدرات

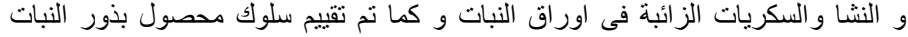

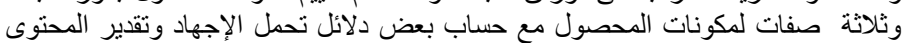

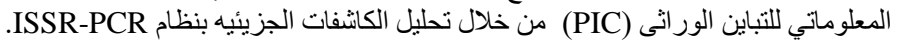

أظهرت النتائج وجود فروق معنوية فى محتوى النبات من الكلوروفيل و الكاروتينات

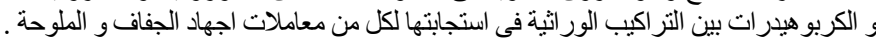

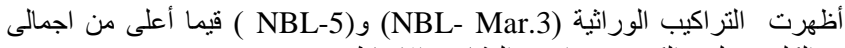

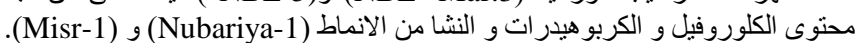

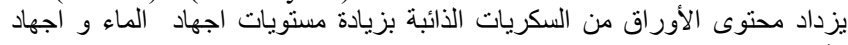

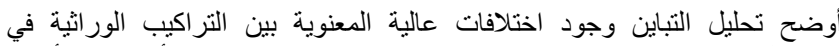

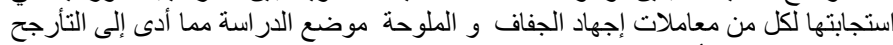
في القيم المحسوبة لأحد عشر من دلالات أحمل تحل الإجهاد.

أظهرت السلالتان (المستنبطنان حديثا من خلال برنامج تربيه الفول البلدى لتحمل

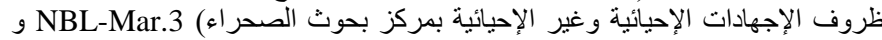
NBL-5

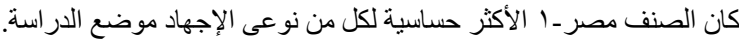

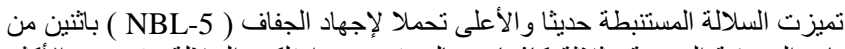

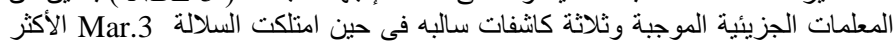

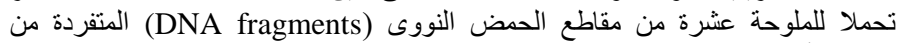
مجموع أربعين من الكاشفات الجزيئية المتخصصة علونة التي نم التعرف عليها بعد تحليل نتائج

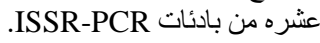

أبدت السلالتانالناتجتان من برنامج التربية لتحمل الإجهاد نسبة عالية من التقارب

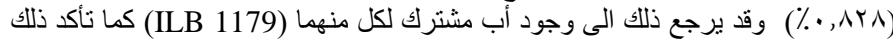

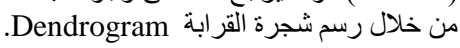

أعطى المحتوى المعلوماتي للتباين الوراثي (PIC) قيما تراوحت بين 7 ـ 9 و , . للبادئ HB12

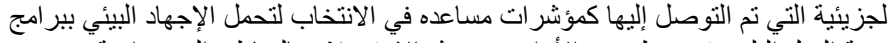

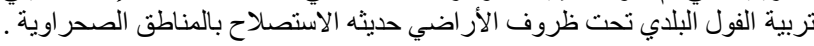

